\title{
The Role of Agriculture in Reducing Child Undernutrition in Nigeria
}

Mulubrhan Amare, Bedru Balana, and Adebayo Ogunniyi 


\section{CONTENTS}

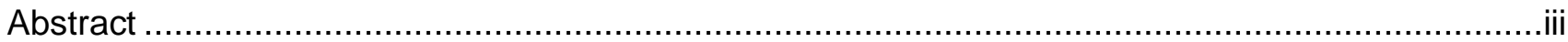

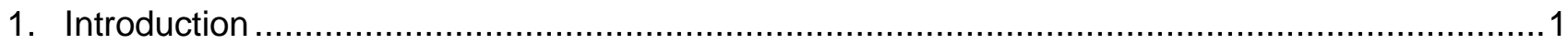

2. Linkages between agricultural productivity change and nutrition outcomes - A REVIEW...........2

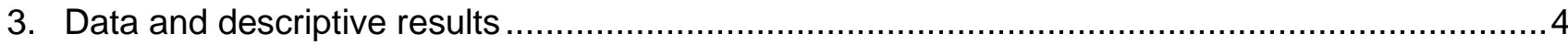

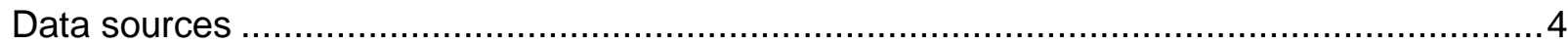

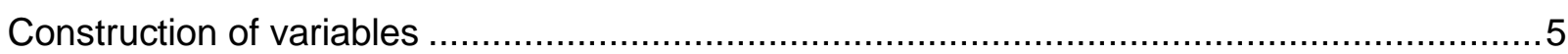

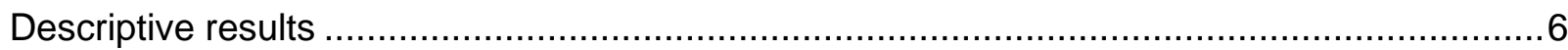

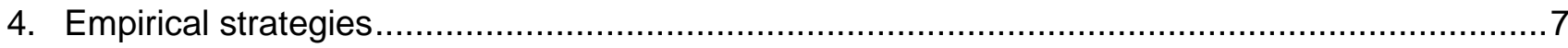

Determinants of agricultural productivity change ..........................................................

Agricultural productivity change and child nutritional outcomes..................................... 8

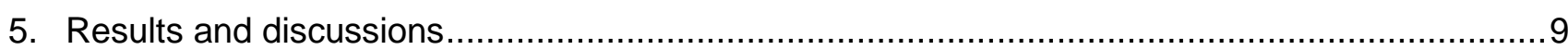

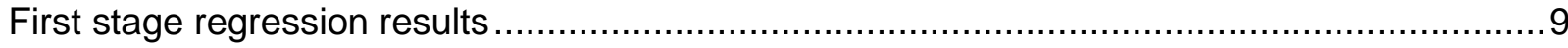

The impact of agricultural productivity change on child nutritional outcomes ......................10

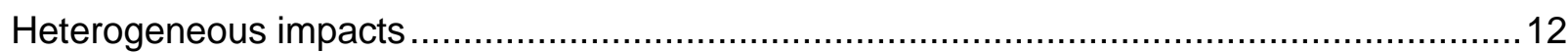

Pathways from agricultural productivity change to child nutritional outcomes....................... 14

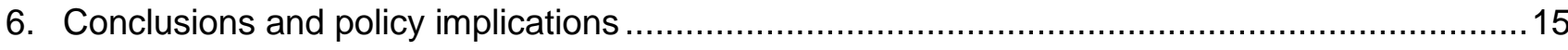

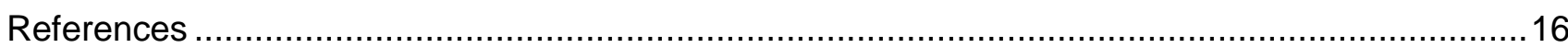

\section{TABLES}

Table 1: Descriptive statistics of variables used in the econometric analysis, full sample................7

Table 2: First stage regression: determinants of agricultural productivity change ........................ 10

Table 3: Impact of agricultural productivity change on child nutritional outcomes........................11

Table 4: Impact of agricultural productivity change on child nutrition outcomes by household access to market

Table 5: Impact of agricultural productivity change on child nutritional outcomes by educational status of household head

Table 6: Impact of agricultural productivity change on total income and household food insecurity status 


\section{ABSTRACT}

This study examines the effect of agricultural productivity change on child nutritional outcomes in Nigeria. Using several waves of micro-level panel data from Nigeria, we first show that high temperature (heat stress) reduces agricultural productivity change. A one percent increase in high temperatures during the crop growth period result in a 4 percent decrease in agricultural productivity. More importantly, our analysis provides several important insights on the implications of agricultural productivity change for reducing child undernutrition. The results show that agricultural productivity growth has a positive effect on child nutritional outcomes, measured by child height-forage and weight-for-age. The main channel through which agricultural productivity growth affects child nutritional outcomes is by increasing food production for own household consumption. This suggests that productivity-enhancing investments in the agricultural sector could have a direct impact on child nutritional outcomes among smallholder households in Nigeria. The results also show that agricultural productivity change has higher impact for households who have better access to markets and a higher educational level. Interventions and policies geared towards intensification of agricultural production need to be complemented with strategies for widening educational programs and improving farmers' access to markets. to induce incentives for increased production. 


\section{INTRODUCTION}

Agricultural interventions focused on intensification of farming and the modernization of market channels for agricultural products can lead to agricultural productivity growth and, thereby, reduce poverty as well as meet growing demands for food. Improving the productivity, profitability, and sustainability of smallholder agriculture is considered as a key pathway out of poverty and food insecurity for many rural households (Ehui and Pender 2005; Gulati et al. 2012; Webb and Block 2012). Byerlee et al. (2009) emphasized the new paradigm of agriculture's role and its multiple functions for development, with a focus on the effects of rising productivity of smallholder agriculture on poverty reduction and household food and nutrition security. In this regard, smallholder-focused inclusive agricultural productivity growth will play a key role not only for poverty reduction but also for structural transformation of the agricultural sector. An increased level of specialization and market-oriented production of high value crops by smallholders could be a salient feature of such a transformation. This could, ceteris paribus, increase overall productivity, create marketing opportunities, and provide additional income, thereby helping smallholders move out of poverty, enable them to afford more diversified diets, and improve their food security (Irz et al. 2001, Minten and Barrett 2008; Christiaensen 2011). However, agricultural productivity growth may not necessarily translate into improved child nutritional outcomes (Berti et al. 2004; Hawkes and Ruel 2008). An increased level of commercialization and production of high-value crops may occur at the expense of growing diverse food crops, which may lead to a decrease in household food selfsufficiency and dietary diversity. Secondly, diversification into high-value crops may change household consumption behavior such that households may sell the food crops they produce rather than consuming them at home.

There is well-established evidence on the linkages between agricultural productivity growth and poverty reduction. Among the possible pathways through which agricultural productivity can reduce poverty, for instance, are through increased incomes and increased household consumption (Minten and Barret 2008; Schneider and Gugerty 2011; Christiaensen 2011). Agriculture also has the potential to reduce undernutrition. However, explicit evidence is thin on the linkages between agricultural productivity and nutritional outcomes, often due to a lack of reliable empirical data. Using Living Standards Measurement Study (LSMS) panel survey data from Nigeria, this study examines the key issue, not well explored in the literature, of how agricultural productivity changes and child nutritional outcomes are linked in the presence of unobserved heterogeneity, which could cause an endogeneity problem. We merge LSMS panel data with satellite-based precipitation and temperature data to deal with unobserved heterogeneity and exploit exogenous variation in rainfall and temperature during the growing season to proxy for exogenous changes in agricultural productivity growth. That is, we use exogenous variation in rainfall and temperature as an instrument for agricultural productivity growth.

This identification strategy is based on the premise that variability in precipitation and temperature are exogenous to agricultural productivity change, and, thus, we examine the effects of agricultural productivity growth on the nutritional outcomes of children. Similar identification strategies have been applied in recent studies. For instance, Chaijaroen (2019) used changes in sea surface temperature as exogenous causes of variations in coral bleaching and its impact on incomes of coastal households in Indonesia. Emerick (2018) used increases in agricultural productivity caused by rainfall variability to examine its impact on sectoral reallocation of labor in India. Emerick extended this analysis to examine the distributional implication of agricultural productivity change on child nutritional outcomes by rural versus urban and geographical zones, obtaining insights for designing policies to both improve agricultural productivity and reduce child undernutrition. 
We specify and estimate two-stage fixed effects models. In the first stage, we estimate agricultural productivity, specified in a Cobb-Douglas production functional form, using exogenous variations in precipitation and temperature among the other explanatory covariates. In the second stage, a fixed effects instrumental variable (FE-IV) model that links agricultural productivity and child nutritional outcomes was estimated using the estimated value agricultural productivity as an instrument (p-hat) with other household characteristics. Results from the first-stage model show that variability in precipitation and temperature strongly predicts agricultural productivity change, which implies the fitness of these exogenous factors as instruments. The results from the second stage FE-IV model indicate that an increase in agricultural productivity has a positive impact on child nutritional outcomes, as measured by child height-for-age and weight-for-age. These nutritional outcomes are obtained mainly through a 'food production - own consumption' causal pathway. Examining the heterogeneity in the impact of agricultural productivity by education level and market access, our results show that child nutritional outcomes are stronger for households with higher education level and better access to market centers than the median values in the sample. This suggests that interventions and policies geared towards intensification of production need to be complemented with strategies for widening educational programs and improving farmers' access to markets. in order to induce incentives for increased production.

The remainder of the paper is organized as follows. Section 2 presents a concise review of literature on the linkages between agricultural productivity and nutritional outcomes. Section 3 describes data sources, the construction of variables, and the descriptive results. Empirical model development and identification strategies are presented in section 4 . Section 5 reports the findings and discussions of the results. The final section concludes the paper with key policy messages.

\section{LINKAGES BETWEEN AGRICULTURAL PRODUCTIVITY CHANGE AND NUTRITION OUTCOMES - A REVIEW}

Issues connecting agricultural productivity to food and nutrition security outcomes are receiving increasing attention in Africa (Frison et al. 2006; Headey et al. 2012; Gómez and Ricketts 2013; Kadiyala et al. 2014; Kassie et al. 2015; Abay and Hirvonen 2016; Zeng et al. 2017; Ruel et al. 2018; Ecker 2018; Tomich et al. 2019). Several pathways that link agriculture to nutrition have been identified. These pathways are influenced by different actors and factors, such as climate change, agricultural practices, income changes, market and consumer demands, employment generation, rural nonfarm multiplier effects, food price effects, and nutrition-relevant policies and programmes (Christiaensen et al. 2011; Haddad and Meeker 2013; Gollin et al. 2014; Abay and Hirvonen 2016; Zeng et al. 2017; Ruel et al. 2018; Ecker 2018). Therefore, the pathways from agricultural production to nutrition outcomes are dynamic and may not necessarily be linearly connected (Haddad and Meeker 2013; Kadiyala et al. 2014; Yosef et al. 2015).

Several studies have shown that investing in agricultural development is significant for poverty reduction, income growth, macro-economic transformation, household food security, and employment creation in the economies of sub-Saharan Africa (Gowing and Palmer 2008; Christiaensen et al. 2011; IMF 2012; Collier and Dercon 2014; Kassie et al. 2015; FAO 2016; World Bank 2017; ILO 2018; Matthew et al. 2019). Despite the high potential and role that agriculture could play in the region, the productivity of the sector remains low (Collier and Dercon 2014; Kassie et al. 2015; World Bank 2017; Matthew et al. 2019). Major factors have been identified for low agricultural productivity in Africa, including poor investment in agricultural research; low application of improved agricultural inputs, such as fertilizer and high yield varieties; low adoption of improved technologies, e.g., mechanization; institutional constraints, such as land tenure insecurity; political or social instability; lack of access to agricultural extension services; poor access to credit facilities; 
low labor productivity due, in part, to low technical know-how; poor market access, and inadequate infrastructure (Ehui and Pender 2005; Christiaensen et al. 2011; Shiferaw et al. 2014; Kassie et al. 2014).

Besides the aforementioned factors, the impact of climate change on agricultural productivity should not be ignored. With agricultural production dependent mainly on rainfall, the effects of abnormal rainfall patterns, whether shortages and excesses, and increase in temperature affect agricultural production and productivity in sub-Saharan Africa (Shiferaw et al. 2014; Belloumi 2014; Kassie et al. 2014; Fisher et al. 2015; Rippke et al. 2016; Powlson et al. 2016; Amare et al. 2018a; Cooper et al. 2019). The adverse effects of climate change on agricultural production can have negative effects on household food security and child nutrition outcomes through several pathways, including reduced yields, shifts in economic incentives, increases in food prices, changes in employment opportunities, changes in sources and distribution of income, and changes in the nutritional content of foods (Chijioke et al. 2011; Belloumi 2014; Cooper et al. 2019). Studies in Nigeria have shown that rises in temperature and abnormal rainfall patterns as a result of climate change are negatively affecting agricultural productivity and consequentially affecting human and livestock health (Chijioke et al. 2011; Aregbosola, et al. 2014; Abidoye and Ayodele 2015).

There are multiple pathways through which agricultural productivity can improve the nutrition and food security of farm households. The most fundamental and direct pathway is the 'production - household's own consumption' linkage. Improvements in the quantity of food produced by the smallholder farming household can be used for its own consumption. Through this pathway, deficits in micronutrients or calories can be supplied by the increase in own-farm productivity (Potts and Nagujja 2007; Masset et al. 2011; Zeng et al. 2017; Kassie et al. 2015; Tomich et al. 2019).

Second, the income effects due to increased sales or increased labor demand from improved agricultural production can positively influence nutrition outcomes indirectly through income and expenditure routes. For instance, income generated from agricultural wages earned as farm workers or from the sale of an increased quantity of produce can be used to purchase nutritious food not produced in the household (Webb and Block 2012; Bhagowalia et al. 2012; Du et al. 2015; Tomich et al. 2019). Headey (2011) and Webb and Block (2012) found that high agricultural growth rates in developing countries were found to reduce stunting rates, possibly because of the increased returns to agricultural production enabling greater household expenditure on food.

Third, agricultural productivity can influence nutrition through women's empowerment. Studies have shown that the nutrition and welfare effects due to increased income from higher agricultural productivity interacts with the empowerment of women in developing countries (Allendorf 2007; Ghosh 2007; Sauer et al. 2016; de Jager et al. 2017). Conceptually, the empowerment of women pathway couples increased income with women-friendly agricultural technologies and leads to increased intra-household bargaining power for women and strengthened purchasing power. Hence, since women are mostly responsible for issues around household nutrition, especially for their children, this may facilitate increased consumption of nutritious food for children in the household (Hallman et al. 2003; Allendorf 2007; Ghosh 2007).

Fourth, agricultural productivity can also affect nutrition outcomes through food price effects. Higher food crop productivity can result in downward pressure on food prices in local markets (Adhiguru and Ramasamy 2003; Parasuraman and Rajaretnam 2011; Webb and Kennedy 2014). For net food consumers, a reduction in food prices enables greater accessibility to food and essential nutrients (Kadiyala et al. 2014; Tomich et al, (2019). On the other hand, Tomich et al, (2019) noted that low food prices could have long-term negative effects on agriculture production stability, declines in productivity, lower availability of food crops, and, ultimately, may result in scarcity of major food crops and higher food prices. Studies have shown that high food prices play an important role in reducing dietary diversification and in adverse nutritional outcomes (Adhiguru 
and Ramasamy 2003; Parasuraman and Rajaretnam 2011; Gaiha et al. 2012; Abay and Hirvonen 2016). Thus, the food price effects pathway between agricultural productivity and nutritional outcomes may not yield a sustainable solution unless adequate policies are in place to stabilize prices and protect farmers from price volatility.

In principle, effective pro-poor growth approaches led by agriculture should be influenced by increased agricultural productivity linked to improved access to markets (Lagakos and Waugh 2013; Duranton 2015; Tombe 2015; Donaldson and Hornbeck 2016; Donovan 2017; Donaldson 2018). Improved agricultural productivity without effective market access will hinder both expected short and long run outcomes of higher levels of production, such as increased incomes, livelihood diversification, and food and nutrition security (Donovan 2017; Donaldson 2018).

Human capital has also been identified as contributing beneficially to several pathways between agricultural productivity and improved nutrition, while also playing significant role in improving agricultural productivity. Enhancing farmers' knowledge and their exposure to technological innovations through training is a key input to improving agricultural productivity (Asfaw and Admassie 2004; Reimers and Klasen 2012; Danso-Abbeam et al. 2018; Mariyono 2019; Anang et al. 2020). Education may not only influence the decision of farmers to adopt new agricultural technology, but also affect their farming creativeness, innovative ability, and technical efficiency. Moreover, education can play an indirect role in improving agricultural productivity through enhancing off-farm employment opportunities, income diversification, and improving household resilience (Asfaw and Admassie 2004; Reimers and Klasen 2012; Liu et al. 2014; Mutisya et al. 2016, Reimers and Klasen 2012). Therefore, education through its role in improving agricultural productivity can lead to improved child nutritional outcomes within farming households.

Against this backdrop, we empirically investigate the pathways linking agricultural productivity to the nutritional status of children within smallholder households in Nigeria.

\section{DATA AND DESCRIPTIVE RESULTS}

\section{Data sources}

The study uses two waves from the Living Standards Measurement Study - Integrated Surveys on Agriculture (LSMS-ISA) panel data set in Nigeria - wave 2 collected in 2012/13 and wave 3 collected in 2015/16. ${ }^{1}$ The LSMS-ISA data sets are nationally representative and include detailed information on demographic and household characteristics, including on assets, agricultural production, nonfarm income and other sources of income, family and hired labor, and access to services. The agriculture module contains information on crop and livestock production, farm technologies employed, use of modern inputs, and the productivity of crops and livestock. The community-level instrument contains information on local infrastructure, basic public goods, local agricultural land, precipitation, and other factors that could affect agricultural productivity. Additionally, there is a module on healthcare utilization and child anthropometrics, in which information is collected on the age, height, and weight of preschool children in survey households. Given a general deficiency in the availability of high-quality agricultural data in Nigeria, the LSMSISA is the best nationally representative data set to use to understand the structure and performance of the agricultural sector.

Georeferences for the location of the survey enumeration areas are provided in the LSMS-ISA survey data set. This permits spatial data to be linked to the survey data on households and their

${ }^{1}$ Wave 4 (2017/2018) LSMS ISA data was released recently. However, we could not use this data because of the sample was rebalanced, leading to significant dropouts of sample households from Waves 2 and 3 . This high rate of attrition is likely to create biasedness in any econometric estimation. 
farm plots. Based on this locational information, we merged the LSMS-ISA data with temperature data extracted from NASA MERRA-2 (Modern-Era Retrospective analysis for Research and Application). We develop monthly mean, maximum, and minimum temperatures in degrees Celsius over the period from 1986 to 2016 at a spatial resolution of $0.50^{\circ} \times 0.625^{\circ}(\sim 55 \mathrm{~km} \times 69 \mathrm{~km})(\mathrm{GMAO}$ 2015). Similarly, we extract monthly precipitation data in millimeters for the period 1981 to 2017 at a spatial resolution of $0.05^{\circ} \times 0.05^{\circ}(\sim 5 \mathrm{~km} \times 5 \mathrm{~km})$ from the Climate Hazards Group InfraRed Precipitation Station (CHIRPS) archives provided by the Climate Hazard Group (Funk et al. 2015; Novella and Thiaw 2013).

\section{Construction of variables}

Anthropometric measures: We used the Anthro software of the World Health Organization for the computation of mean z-scores for height-for-age (HAZ), weight-for-age (WAZ), weight-for-height (WHZ) for all children under the age of five years in the survey sample. The assignment of anthropometric z-scores was based on the WHO Child Growth Standards and considered a child's sex, age, height in centimeters, and weight in kilograms (WHO Multicentre Growth Reference Study Group 2006). These z-scores were used to estimate the percentage of children who were stunted, wasted, or underweight.

Agricultural productivity: We used land productivity to measure changes in agricultural productivity among the farm households. The productivity of land measures the amount of output generated per unit land (measured in hectares). We expressed the value of crop production in monetary terms. ${ }^{2}$ Hence, land productivity is referred to as net returns to land. ${ }^{3}$

Income aggregates: We generated household income aggregates by combining farm income and non-farm income. Farm income comprises crop income and livestock income, while non-farm income includes income from self-employment; fishing (artisanal); wages, including agricultural wages; and other income sources, such as rental incomes, transfers or remittances, and other revenue streams not captured elsewhere.

Income sources: Different methods were used to construct household income from different sources. We calculated crop income by using the total value of crop production minus total crop expenses; livestock income was generated from the value of livestock production and consumption minus livestock expenditures; self-employment income was computed from the profit of processed crops sold and from reported self-employment income; wage income was generated from wages earned from work both in the agricultural and non-agricultural sector; and other source of income comprises the sum of investment income, rental income, and remittance income.

Climate variables: We construct three measures of climate variability.

i) Deviation of log rainfall from average (DR). The variable was constructed using spatial precipitation data. DR measures rainfall anomalies by first calculating the average total rainfall across the rainy months (March through October) in each survey enumeration area for a 30-year baseline period from 1986 to $2016 .{ }^{4}$ The change in the rainfall variable is defined as the deviation of log rainfall from the average using: $\mathrm{DR}_{i t}=\ln \left(\mathrm{R}_{i t}\right)-\ln \left(\overline{\mathrm{R}}_{i}\right)$, where $\mathrm{R}_{i t}$ indicates rainfall during a

\footnotetext{
${ }^{2}$ As with other inputs, land productivity can be expressed in many units. Given that the land may be used to grow many different crops, a physical unit, such as metric ton or kilogram, may not be the best choice. Putting a monetary value on their respective output is often needed to aggregate the output of different crops.

${ }^{3}$ Net crop income is calculated as gross crop income minus crop expenses. The costs of agricultural production are the sum of all explicit crop expenses reported in each survey. The value of harvest is the value of crop production. Crop production is valued either by the respondent's own valuation (if available) or by multiplying quantities produced by the sales values observed by the head of household for each crop if he or she sold that crop. If the household did not sell a crop that the household produced, the value per unit is imputed using the median per-unit value of observed sales at the smallest geographic unit for which we have at least 10 observations.

${ }^{4}$ The annual rainy season is usually between March and October in the Nigeria. However, we captured difference between northern Nigeria and southern Nigeria. For northern Nigeria, the effectiveness of weather variables can be well captured between May and October, while March to October is more accurate for southern Nigeria.
} 
specific rainy season at the location of household $i$ for year $t . \overline{\mathrm{R}}_{\iota}$ is the historical average rainfall over the period from 1986 to 2016 at the location of household $i$.

ii) Growing Degree Days (GDD). We follow the agronomic literature and use Growing Degree Days (GDD) and Harmful Degree Days (HDD) to estimate the impact of temperature on agricultural yield and value (Schlenker and Roberts 2006; Lobell et al. 2011; Lobell et al. 2013; Deryng et al. 2014; Hendricks and Peterson 2014; Jagnani et al. 2019; Aragón et al. forthcoming). GDD is calculated using the cumulative exposure to temperatures between a lower bound (the standard base temperature of $10^{\circ} \mathrm{C}$ ) up to an upper threshold of $30^{\circ} \mathrm{C}$. We calculate GDD for each month over the last 30 years (1985-2016) by subtracting the standard base temperature of $10^{\circ} \mathrm{C}$ from the mean temperature for each month of rainy season. We then subtract the average season GDD for the last 30 years for each crop cycle from the GDD for each of the waves of data collected. Thereby, we derive the GDD deviation, $\mathrm{DGDD}$, for each wave during the respective rainy season for each survey household as $\mathrm{DGDD}_{i t}=\ln \left(\mathrm{GDD}_{i t}\right)-\ln \left(\overline{\mathrm{GDD}}_{i}\right)$.

iii) Harmful Degree Days (HDD). We defined degree days above $30^{\circ} \mathrm{C}$ (GDD>30) as Harmful Degree Days (HDD) to capture days with heat stress that can reduce crop production physiologically. As with GDD, we calculated the HDD deviation (DHDD) as the log HDD difference from the average HDD. This represents the deviation from the mean for harmful degree days. In essence, DHDDs are anomalies relative to the mean of temperature over the 30-year period.

\section{Descriptive results}

Table 1 shows the nutritional status of children measured according to HAZ, WAZ and WHZ. The average HAZ for all children in the sample is -1.01 . We found that about 31 percent of the children in our sample are stunted (HAZ <-2.0). Sixteen percent of the children in our sample are underweight (WAZ <-2.0). Children in rural households have a significantly higher mean $\mathrm{HAZ}$ and also a higher mean WAZ than children in urban households. The difference in HAZ, especially, is relatively large, which is also reflected in stunting prevalence rates. Meanwhile, the average $\mathrm{WHZ}$ for all the sample children is -0.03 and 11 percent of the children are wasted. Consistent with stunting and underweight, a higher rate of child wasting is observed in rural households than urban households.

Table 1 also presents the summary statistics of key variables used in the econometric models. It is important to note that values in the table were averages obtained from the two waves. The results show that the proxy for average agricultural productivity (land productivity) of real net crop income is USD 2,480 (PPP) per hectare. We recorded the deviation from the long-term mean of our instrumental variable of rainfall and temperature, as DGDD and DHDD - the standardized score of deviation from the long-term mean for GDD and for HDD is 0.06 and 0.03 , respectively. ${ }^{5}$

\footnotetext{
${ }^{5}$ We restrict the data to farm households for which the agricultural questionnaire was completed and for which data on rainfall at the household level are available.
} 
Table 1: Descriptive statistics of variables used in the econometric analysis, full sample

\begin{tabular}{|c|c|c|}
\hline & Mean & $\begin{array}{l}\text { Standard } \\
\text { Deviation }\end{array}$ \\
\hline \multicolumn{3}{|l|}{ Outcome variables } \\
\hline \multicolumn{3}{|l|}{ Child nutritional outcomes } \\
\hline Height-for-age z-score (HAZ) & -1.01 & 2.50 \\
\hline Weight-for-height Z-score (WHZ) & -0.03 & 2.35 \\
\hline Weight-for-age z-score (WAZ) & -0.67 & 1.69 \\
\hline \multicolumn{3}{|l|}{ Child undernutrition prevalence rates } \\
\hline Child stunting (HAZ <-2), 0/1 & 0.31 & \\
\hline Child wasting $(\mathrm{WHZ}<-2), 0 / 1$ & 0.11 & \\
\hline Child underweight $($ WAZ $<-2), 0 / 1$ & 0.16 & \\
\hline \multicolumn{3}{|l|}{ Agricultural productivity } \\
\hline Land productivity - real net crop income per hectare, PPP USD & $2,479.8$ & $3,190.7$ \\
\hline \multicolumn{3}{|l|}{ Instruments } \\
\hline DR - Deviation of log rainfall from average (long term mean) & -0.05 & 0.16 \\
\hline DGDD - Deviation of log Growing Degree Days from average (long term mean) & 0.06 & 0.17 \\
\hline DHDD - Deviation of log Harmful Degree Days from average (long term mean) & 0.02 & 0.02 \\
\hline \multicolumn{3}{|l|}{ Explanatory variables } \\
\hline Boy child, 0/1 & 0.52 & 0.50 \\
\hline Age of child, months & 31.2 & 17.53 \\
\hline Family size, adult equivalents & 6.10 & 3.11 \\
\hline Female head of household, 0/1 & 0.06 & \\
\hline Educational attainment of household head, years & 7.2 & 6.03 \\
\hline Age of household head, years & 46.1 & 10.98 \\
\hline Total assets value, PPD USD & $1,018.5$ & $1,864.7$ \\
\hline Livestock, Tropical Livestock Units & 58.67 & 230.91 \\
\hline Wage non-agricultural income, PPP USD & $1,395.3$ & $4,150.5$ \\
\hline Wage agricultural income, PPP USD & 20.7 & 199.0 \\
\hline Self-employment income, PPP USD & $2,081.4$ & $4,432.2$ \\
\hline Remittances, PPP USD & 8.09 & 75.76 \\
\hline Access to finance (credit use), $0 / 1$ & 0.02 & \\
\hline Used fertilizer, 0/1 & 0.40 & \\
\hline Used pesticides or herbicides, 0/1 & 0.27 & \\
\hline Access to agricultural extension, $0 / 1$ & 0.07 & \\
\hline Distance to market, $\mathrm{km}$ & 70.30 & 43.15 \\
\hline Number of observations & 7,180 & \\
\hline
\end{tabular}

Source: Authors' calculations based on Nigeria LSMS-ISA 2012 and 2015.

Note: Productivity, wealth, and income values are computed as purchasing power parity in U.S. dollars unit (PPP USD).

\section{EMPIRICAL STRATEGIES}

Here we discuss our empirical approach to investigate the two main objectives of this study. First, we examine the determinants of agricultural productivity change. Second, we address the implication of agricultural productivity change for child nutritional outcomes.

\section{Determinants of agricultural productivity change}

We measure agricultural productivity $\left(P_{i t}\right)$ as the real net crop income per ha. We use a CobbDouglas production function as follows:

$$
\ln \left(P_{i t}\right)=\gamma_{i t}+\beta_{x} \ln \left(X_{i t}\right)+\beta_{h} \ln \left(H_{i t}\right)+\beta_{r} \mathrm{DR}_{i t}+\beta_{g} \mathrm{DGDD}_{i t}+\beta_{h} \mathrm{DHDD}_{i t}+v_{i}+v_{t}+\varepsilon_{i t},
$$

where $X_{i t}$ is a vector of quantities of inputs and plot characteristics, including labor inputs, seeds, fertilizer, and herbicide or pesticide by household $i$ in year $t$. We expect all farm technology variables to contribute positively to productivity. $H_{i t}$ is a vector of household characteristics and 
wealth indicators, including household size, age, and income from remittances, wages, and selfemployment for household $i$ in year $t . \mathrm{DR}_{i t}$ is deviation of log rainfall from long term average. DGDD $i t$ and $\mathrm{DHDD}_{i t}$ are deviation of log growing degree days and harmful degree days from long term average for household $i$ in year $t$, respectively. We also include higher order polynomial terms associated with these changes to control nonlinear effects of changes in rainfall and temperature. The variables $v_{i}$ and $v_{t}$ represent household and time-fixed effects, respectively. The variable $\varepsilon$ is a mean zero, identically and independently distributed random error and is assumed to be uncorrelated to all the explanatory variables.

The problem in estimating the drivers of agricultural productivity is that unobserved characteristics, e.g., information about inputs, managerial skill, ability, or additional dimensions of soil quality, are likely to be correlated with productivity and the variables of interest. This correlation could bias ordinary least squares (OLS) estimators (Wooldridge 2010). We exploit the panel nature of the dataset to minimize such prospective bias. The fixed effects, $v_{i}$ and $v_{t}$, help to ensure that the estimated effects of variables are not due to differences in common time shocks or technical progress or to household- and village-invariant unobserved characteristics, respectively.

\section{Agricultural productivity change and child nutritional outcomes}

We estimate the impact of agricultural productivity on child nutritional outcomes using a function of the following form:

$$
\ln \left(C_{i t v}\right)=\gamma_{0}+\gamma_{p} \ln \left(\mathrm{P}_{i t v}\right)+\gamma_{h} \ln \left(\mathrm{H}_{i t v}\right)+\varsigma_{i}+\lambda_{p}+\eta_{i t} .
$$

The dependent variable used in the regression analysis is the child nutritional outcomes $\left(C_{i t}\right)$ at village level $\mathrm{v}$. The child nutritional outcome of interest is captured by the coefficients on $\mathrm{P}_{i t}$, which is agricultural productivity. $H$ and $P$ are as defined above. Because similar intrinsic demographic characteristics can lead to different asset distribution patterns, a household fixed effect, $s_{i}$, is included to control for time-invariant unobserved demographic characteristics. Furthermore, a statefixed effect, $\lambda_{p}$, is included to control for further geographic diversity in land quality and for covariate shocks affecting all provinces uniformly in each year. The variable $\eta_{i}$ is the error term.

However, agricultural productivity, which is expected to be simultaneously determined with child nutritional outcomes could be an endogenous decision by farm households. Agricultural productivity is also expected to be correlated with unobservable household characteristics that may affect child nutritional outcomes. Thus, OLS would cause upward- or downward-biased estimates (Bellemare 2013; Hausman and Taylor 1981). ${ }^{6}$ More specifically, if a farmer's agricultural productivity is measured with error, and the true value of the impact of agricultural productivity is positive, the OLS estimate will be biased toward zero, even if that error has a mean of zero. Thus, the OLS estimate will be too small because of attenuation bias. The two sources of bias could apply simultaneously to the OLS estimation: the upward bias caused by omitted ability variables and the downward bias caused by measurement error in agricultural productivity (Wooldridge 2010).

Because of this potential endogeneity problem, we investigate the implications of agricultural productivity changes on child nutritional outcomes indicators by employing an instrumental variable (IV) estimation approaches. Most studies of this sort exploit some exogenous variation in agricultural productivity and aim to investigate its effect on child nutritional outcomes. We follow previous literature and use an instrumental variable constructed by matching our panel household data with satellite-based rainfall and temperature data (Chaijaroen 2019; Emerick 2018). We use

\footnotetext{
${ }^{6}$ OLS would cause upward- or downward-biased estimates if all the unobservable characteristics have a positive effect on both productivity and the observed RHS variables. But unobservable characteristics can also have a negative impact. For example, consider the case where most of the people who adopt improved seeds live on slopes that reduce crop yield. If we do not observe the slope, we will underestimate the yield improvements associated with improved seed adoption.
} 
deviation from the long average during the wet season. To exploit the panel nature of the dataset, we estimate the following fixed-effects (IV-FE) model for our second-stage.

$$
\ln \left(C_{i t v}\right)=\gamma_{0}+\gamma_{p} \ln \left(\widehat{\mathrm{P}}_{i t v}\right)+\gamma_{h} \ln \left(\mathrm{H}_{i t v}\right)+\varsigma_{i}+\lambda_{p}+\eta_{i t v},
$$

$\widehat{\mathrm{P}}_{i t}$ is the predicted value of agricultural productivity from our first-stage regression. Other notations in Equation 3 are similar to those in Equations 1 and 2.

\section{RESULTS AND DISCUSSIONS}

\section{First stage regression results}

We first briefly report the results of the first stage estimates of the determinants of agricultural productivity change using a fixed-effects model (Equation 1). Table 2 presents these results. The first stage estimation is mainly used in the later FE-IV analysis to explain child nutritional outcomes (Equation 3). As expected, negative rainfall shock strongly affects agricultural productivity. In Table 2 we present both conditional and unconditional regressions of agricultural productivity change on measures of deviation of rainfall, growing degree days, and harmful degree days from average and their higher order polynomial terms. Our results show that climate variability strongly predicts agricultural productivity change. The relationship involves significant nonlinearities, indicating that these types of nonlinearities and dynamics are evident on agricultural productivity change. This is consistent with previous studies, e.g., Hendricks and Peterson 2014; Jagnani et al. 2019; Aragón et al., forthcoming. The results show that high temperature (heat stress) reduces changes in agricultural productivity. A one percent increase in DHDD result in a 4 percent decrease in agricultural productivity.

The results also indicate that among household characteristics, education of the household head and livestock holdings significantly affect agricultural productivity change. The estimates also show the presence of an inverse relationship between farm size and land productivity robust to all estimation specifications and consistent with many other findings in the literature (Barrett 1996; Carletto et al. 2013). We find that fertilizer use, application of herbicides or pesticides, and access to extension all have a significant, positive association with agricultural productivity change. Our results are consistent with several studies that demonstrate that input use has a substantial effect on the agricultural performance of farmers (e.g., Amare et al. 2012; de Janvry and Sadoulet 2010; Mendola 2007; Ravallion and Datt 1999). Distance to markets increases transaction costs and access to information, which, in turn, affect agricultural productivity. This result suggests that better infrastructure may help to cut transaction costs, increasing the likelihood of adoption of marketprovided inputs and, thus, increasing agricultural productivity. 
Table 2: First stage regression: determinants of agricultural productivity change

\begin{tabular}{|c|c|c|}
\hline & $\begin{array}{l}\text { (1) } \\
\text { Agricultural } \\
\text { productivity }\end{array}$ & $\begin{array}{l}\qquad(2) \\
\text { Agricultural } \\
\text { productivity }\end{array}$ \\
\hline \multirow[t]{2}{*}{ Deviation of rainfall from average } & 0.003 & 0.007 \\
\hline & $(0.118)$ & $(0.114)$ \\
\hline \multirow[t]{2}{*}{ Deviation of rainfall from average-squared } & $-0.217^{\star \star \star}$ & $-0.194^{\star *}$ \\
\hline & $(0.109)$ & $(0.061)$ \\
\hline \multirow[t]{2}{*}{ Deviation of Growing Degree Days from average } & $-0.112^{\star \star *}$ & $-0.109 * * *$ \\
\hline & $(0.014)$ & $(0.014)$ \\
\hline \multirow[t]{2}{*}{ Deviation of Growing Degree Days from average-squared } & $-0.682^{\star \star \star}$ & $-0.673^{\star \star \star}$ \\
\hline & $(0.192)$ & $(0.181)$ \\
\hline \multirow[t]{2}{*}{ Deviation of Harmful Degree Days from average-squared } & $-0.385^{\star \star}$ & $-0.366^{\star \star}$ \\
\hline & $(0.168)$ & $(0.155)$ \\
\hline \multirow[t]{2}{*}{ Education of head } & & $0.089 * \star$ \\
\hline & & $(0.044)$ \\
\hline \multirow[t]{2}{*}{ Land size } & & $-0.633^{\star \star *}$ \\
\hline & & $(0.024)$ \\
\hline \multirow[t]{2}{*}{ Livestock } & & $0.555^{\star \star}$ \\
\hline & & $(0.277)$ \\
\hline \multirow[t]{2}{*}{ Value of total assets } & & -0.042 \\
\hline & & $(0.037)$ \\
\hline \multirow[t]{2}{*}{ Wage income } & & $-0.097^{\star \star \star}$ \\
\hline & & $(0.019)$ \\
\hline \multirow[t]{2}{*}{ Self-employment income } & & $-0.072^{\star \star \star}$ \\
\hline & & $(0.019)$ \\
\hline \multirow[t]{2}{*}{ Transfer } & & 0.041 \\
\hline & & $(0.066)$ \\
\hline \multirow[t]{2}{*}{ Credit use } & & 0.125 \\
\hline & & $(0.250)$ \\
\hline \multirow[t]{2}{*}{ Extension } & & $0.442^{\star \star}$ \\
\hline & & $(0.193)$ \\
\hline \multirow[t]{2}{*}{ Fertilizer } & & $1.413^{\star \star \star}$ \\
\hline & & $(0.158)$ \\
\hline \multirow[t]{2}{*}{ Pesticides/herbicides } & & $0.193^{\star *}$ \\
\hline & & $(0.090)$ \\
\hline \multirow[t]{2}{*}{ Distance to market } & & $-0.255^{\star \star \star}$ \\
\hline & & $(0.087)$ \\
\hline \multirow[t]{2}{*}{2015} & $0.297^{\star \star \star}$ & $0.149^{*}$ \\
\hline & $(0.092)$ & $(0.089)$ \\
\hline \multirow[t]{2}{*}{ Constant } & $5.773^{\star \star \star}$ & $4.343^{\star \star \star}$ \\
\hline & $(0.517)$ & $(0.613)$ \\
\hline Fixed effects & Yes & Yes \\
\hline Observations & 7,180 & 7,180 \\
\hline Kleibergen-Paap rk Wald F statistic on selection instruments & $18.23^{\star \star \star}$ & 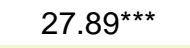 \\
\hline F-test of excluded instruments: F $(2,6585)$ & $36.01^{\star \star \star}$ & $32.92^{\star \star \star}$ \\
\hline
\end{tabular}

Source: Based on LSMS-ISA W1-2012 and W3-2016 survey in Nigeria. Note: All continuous variables are in log form. Enumeration area clustered standard errors in parentheses. ${ }^{*} p<0.10,{ }^{* *} p<0.05$, ${ }^{* *} p<0.01$.

\section{The impact of agricultural productivity change on child nutritional outcomes}

Before turning to look at the impact of agricultural productivity on child nutritional outcomes, we briefly discuss the quality of the selection of the instrument used. To probe the validity of our instrument selection, we look at the weak identification test and the over-identification tests. The test results support the choice of the instrument - deviation of rainfall, growing degree days, and harmful degree days from average, as do the F-test values for all of the specifications (bottom of Table 3 ). 
The F-statistic on the null hypothesis that the excluded instrument is jointly nonsignificant in the firststage equation is greater than 10 , thus passing the rule-of-thumb minimum threshold for weak instruments. We use the Sargan-Hansen test of over-identifying restrictions and fail to reject the joint null hypothesis that our instrument is a valid instrument. We also apply the Hansen specification test for the endogeneity of agricultural productivity and reject the null hypothesis that agricultural productivity can actually be treated as exogenous.

Table 3: Impact of agricultural productivity change on child nutritional outcomes

\begin{tabular}{|c|c|c|c|c|c|c|}
\hline & $\begin{array}{l}(1) \\
\text { Height-for- } \\
\text { Age } \\
\text { z-score }\end{array}$ & $\begin{array}{l}\text { (2) } \\
\text { Weight-for- } \\
\text { Height } \\
\text { z-score }\end{array}$ & $\begin{array}{c}\text { (3) } \\
\text { Weight-for- } \\
\text { Age } \\
\text { z-score }\end{array}$ & $\begin{array}{c}\text { (4) } \\
\text { Stunting } \\
\text { prevalence }\end{array}$ & $\begin{array}{c}\text { Wasting } \\
\text { prevalence }\end{array}$ & $\begin{array}{l}\text { Underweight } \\
\text { prevalence }\end{array}$ \\
\hline \multirow[t]{2}{*}{ Agricultural productivity change } & $0.202^{\star \star \star}$ & $0.082^{\star \star}$ & 0.041 & $-0.046^{\star \star \star}$ & -0.008 & -0.010 \\
\hline & $(0.078)$ & $(0.040)$ & $(0.072)$ & $(0.015)$ & $(0.007)$ & $(0.012)$ \\
\hline \multirow[t]{2}{*}{ Male child, $0 / 1$} & $-0.211^{\star \star \star}$ & $-0.138^{\star \star}$ & -0.050 & $0.048^{\star \star \star}$ & $0.022^{\star \star}$ & $0.044^{\star \star \star}$ \\
\hline & $(0.075)$ & $(0.057)$ & $(0.074)$ & $(0.015)$ & $(0.011)$ & $(0.012)$ \\
\hline \multirow[t]{2}{*}{ Age of child } & 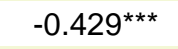 & $-0.152^{\star \star \star}$ & 0.052 & $0.030^{* * *}$ & $-0.054^{\star \star \star}$ & $-0.016^{\star *}$ \\
\hline & $(0.066)$ & $(0.039)$ & $(0.055)$ & $(0.010)$ & $(0.007)$ & $(0.007)$ \\
\hline \multirow[t]{2}{*}{ Education of head } & $0.070^{*}$ & -0.010 & 0.013 & -0.012 & -0.001 & -0.008 \\
\hline & $(0.058)$ & $(0.036)$ & $(0.050)$ & $(0.009)$ & $(0.006)$ & $(0.007)$ \\
\hline \multirow[t]{2}{*}{ Age of head } & -0.048 & -0.030 & -0.004 & 0.025 & 0.010 & 0.021 \\
\hline & $(0.120)$ & $(0.119)$ & $(0.164)$ & $(0.026)$ & $(0.022)$ & $(0.022)$ \\
\hline \multirow[t]{2}{*}{ Value of assets } & $0.087^{\star \star}$ & $0.072^{\star \star}$ & 0.030 & $-0.024^{\star \star \star}$ & -0.002 & $-0.011^{*}$ \\
\hline & $(0.042)$ & $(0.029)$ & $(0.035)$ & $(0.008)$ & $(0.005)$ & $(0.006)$ \\
\hline \multirow[t]{2}{*}{ Farm size } & $0.196^{*}$ & -0.054 & 0.059 & 0.031 & -0.004 & 0.003 \\
\hline & $(0.116)$ & $(0.090)$ & $(0.119)$ & $(0.027)$ & $(0.015)$ & $(0.022)$ \\
\hline \multirow[t]{2}{*}{ Livestock unit } & -0.040 & 0.007 & 0.063 & $0.033^{\star}$ & 0.012 & 0.011 \\
\hline & $(0.107)$ & $(0.082)$ & $(0.115)$ & $(0.019)$ & $(0.015)$ & $(0.015)$ \\
\hline \multirow[t]{2}{*}{ Crop income } & 0.010 & $0.048^{* *}$ & $0.061^{\star \star \star}$ & -0.014 & -0.000 & $0.006^{\star *}$ \\
\hline & $(0.033)$ & $(0.020)$ & $(0.023)$ & $(0.010)$ & $(0.003)$ & $(0.003)$ \\
\hline \multirow[t]{2}{*}{ Non-agricultural wage income } & $0.597^{\star \star *}$ & $0.379^{\star \star \star}$ & 0.039 & $-0.128^{\star \star}$ & -0.015 & -0.044 \\
\hline & $(0.177)$ & $(0.111)$ & $(0.145)$ & $(0.057)$ & $(0.020)$ & $(0.028)$ \\
\hline \multirow[t]{2}{*}{ Agricultural wage income } & -0.507 & 0.362 & 0.906 & 0.069 & 0.102 & $0.233^{*}$ \\
\hline & $(0.616)$ & $(0.545)$ & $(0.596)$ & $(0.111)$ & $(0.123)$ & $(0.135)$ \\
\hline \multirow[t]{2}{*}{ Self-employment income } & 0.055 & 0.116 & 0.109 & -0.031 & 0.006 & -0.001 \\
\hline & $(0.106)$ & $(0.076)$ & $(0.095)$ & $(0.022)$ & $(0.022)$ & $(0.016)$ \\
\hline \multirow[t]{2}{*}{ Transfers income } & 0.375 & 0.235 & 0.109 & -0.245 & -0.156 & 0.107 \\
\hline & $(2.167)$ & $(2.100)$ & $(1.407)$ & $(0.249)$ & $(0.323)$ & $(0.328)$ \\
\hline \multirow[t]{2}{*}{ Credit use } & 0.533 & 0.198 & -0.096 & -0.004 & -0.012 & -0.031 \\
\hline & $(0.416)$ & $(0.256)$ & $(0.186)$ & $(0.057)$ & $(0.034)$ & $(0.047)$ \\
\hline \multirow[t]{2}{*}{ Extension } & -0.152 & -0.027 & 0.172 & 0.028 & 0.024 & 0.016 \\
\hline & $(0.202)$ & $(0.120)$ & $(0.184)$ & $(0.043)$ & $(0.022)$ & $(0.028)$ \\
\hline \multirow[t]{2}{*}{ Distance to market } & $-0.447^{\star \star}$ & -0.218 & $-0.381^{*}$ & -0.042 & -0.026 & -0.053 \\
\hline & $(0.221)$ & $(0.211)$ & $(0.204)$ & $(0.044)$ & $(0.025)$ & $(0.034)$ \\
\hline \multirow[t]{2}{*}{ Year } & $-0.534^{\star}$ & -0.085 & $0.232^{\star *}$ & $0.127^{\star \star \star}$ & $0.022^{*}$ & $0.083^{\star \star \star}$ \\
\hline & $(0.126)$ & $(0.076)$ & $(0.090)$ & $(0.021)$ & $(0.012)$ & $(0.015)$ \\
\hline \multirow[t]{2}{*}{ Constant } & -0.097 & $-1.537^{*}$ & $-1.824^{*}$ & $0.516^{\star \star}$ & $0.297^{\star \star}$ & $0.381^{\star \star}$ \\
\hline & $(1.102)$ & $(0.915)$ & $(1.072)$ & $(0.223)$ & $(0.130)$ & $(0.153)$ \\
\hline $\begin{array}{l}\text { Over identification test of all } \\
\text { instruments (Hansen } \mathrm{J} \\
\text { statistics): } \mathrm{x}^{2}\end{array}$ & $43.614^{\star \star \star}$ & $21.359^{\star \star \star}$ & $15.613^{\star \star \star}$ & $19.487^{\star \star \star}$ & $13.342^{\star \star \star}$ & $10.487^{\star \star \star}$ \\
\hline Endogeneity test & $49.577^{\star \star \star}$ & $13.081^{\star \star \star}$ & $13.062^{\star \star *}$ & $5.151^{\star \star \star}$ & $6.232^{\star \star \star}$ & $4.213^{\star \star \star}$ \\
\hline Observations & 7,180 & 7,171 & 7,180 & 7,180 & 7,180 & 7,180 \\
\hline
\end{tabular}

Source: Based on LSMS-ISA W1-2012 and W3-2016 survey in Nigeria. Note: All continuous variables are given in log form. Enumeration area clustered standard errors in parentheses. ${ }^{*} p<0.10,{ }^{* \star} p<0.05,{ }^{\star \star *} p<0.01$. 
Table 3 reports the results of the IV-FE estimation examining the impact of agricultural productivity change on child nutritional outcomes. The z-score results (columns (1), (2), and (3)) reveal that agricultural productivity increases child height-for-age (HAZ) and weight-for-age (WAZ). A 10 percent increase in agricultural productivity change results in an increase in child HAZ and WAZ by about 0.030 and 0.013 , respectively. Our results suggest that improvement in agricultural production by smallholder farmers can be used for their own household food consumption so that any deficits in micronutrients or calories are supplied by the increase in production from their own farms (Potts and Nagujja 2007; Masset et al. 2011; Zeng et al. 2017; Kassie et al. 2015; Tomich et al. 2019). The findings from Kim et al. (2019) suggest that use of sustainable agricultural intensification practices is associated with improvements in children's height-for-age and weight-forage z-scores, particularly for children aged 25-59 months. Specifically, the study shows that these effects appear to come through improvements in both crop income and productivity. Kumar et al. (2015) also found strong significant positive associations between agricultural productivity (through production diversity) and height for age Z-scores and a reduction in stunting prevalence among children in Zambia.

Looking at child and household characteristics, we find that girls have generally a higher HAZ than boys, which is a common finding in the research literature (e.g., Black et al. 2013, Alderman and Headey 2017a; Amare et al. 2018b). Consistent with the existing literature on child nutrition in developing countries, older children are more likely to have lower nutritional outcomes (e.g., Behrman and Taubman 1986). Education may, among other contributions, enable household to provide appropriate care for their children (Alderman and Headey 2017). We also find education of the household head is strongly and positively associated with improved nutritional outcomes. Wealth indicators, such as land size, value of asset holding, and non-agricultural wage income, play a significant role in explaining changes in child nutritional outcomes.

The results on the prevalence of undernourished children in Table 3 (columns (4), (5), and (6)) reveal that an improvement in agricultural productivity reduces child stunting. A 10 percent increase in agricultural productivity will reduce child stunting by 2 percent. The results also show girls are generally less stunted than boys and older children are more likely to be stunted and wasted, similar to evidence seen in other studies (Behrman and Taubman 1986; Black et al. 2013, Alderman and Headey 2017a). Value of asset holding, livestock holding, and non-agricultural wage income play a positive role in reducing the prevalence of child stunting (Christian et al. 2019; Hatab et al. 2019).

\section{Heterogeneous impacts}

We also estimate the impact of agricultural productivity change on child nutritional outcomes separately using access to market and education level of the household. This was motivated by the premise that pathways for linking agricultural productivity to nutrition may have some heterogeneity which we can test through market access and education. As education plays productivity-enhancing roles through various pathways, such as general-skill building, literacy and numeracy dynamics, etc., high agricultural productivity with adequate market access will lead to increases in income, which positively affect dietary diversification and non-food expenditure, which may be linked, directly or indirectly, to nutritional outcomes for children within the household.

First, we estimate child nutritional outcomes by access to market. A dummy variable for households who have better access to market is defined. A household is designated as to have better access to market if the distance to the nearest market center is below the median distance to market for the households in our sample, i.e., the nearest market center is within $65 \mathrm{~km}$. Households with their nearest market center being beyond $65 \mathrm{~km}$ distance radius are classified as having constrained access to market. 
The results (Table 4) indicate that agricultural productivity change has a positive significant impact on child HAZ and reduces child stunting for households who have better access to market. Controlling for other factors, we find that agricultural productivity change increases child HAZ. A 10 percent increase in agricultural productivity increases child HAZ by 0.05 for households who have better access to market, but it has no significant effect for household who have no or limited access to market. Our finding is consistent with previous studies that found that agricultural productivity changes will have an impactful effect on nutrition outcomes if the households have better access to market (Stifel and Minten 2017; Hirvonen et al. 2017; Headey et al. 2019).

Table 4: Impact of agricultural productivity change on child nutrition outcomes by household access to market

\begin{tabular}{|c|c|c|c|c|c|c|}
\hline & (1) & (2) & (3) & (4) & (5) & (6) \\
\hline & \multicolumn{2}{|c|}{ Child HAZ } & \multicolumn{2}{|c|}{ Child WHZ } & \multicolumn{2}{|c|}{ Child WAZ } \\
\hline & $\begin{array}{l}\text { More market } \\
\text { access }\end{array}$ & $\begin{array}{l}\text { Less market } \\
\text { access }\end{array}$ & $\begin{array}{l}\text { More market } \\
\text { access }\end{array}$ & $\begin{array}{l}\text { Less market } \\
\text { access }\end{array}$ & $\begin{array}{l}\text { More market } \\
\text { access }\end{array}$ & $\begin{array}{l}\text { Less market } \\
\text { access }\end{array}$ \\
\hline \multirow[t]{2}{*}{ Agricultural productivity } & $0.460^{\star \star \star}$ & 0.154 & -0.108 & 0.013 & 0.179 & 0.084 \\
\hline & $(0.163)$ & $(0.204)$ & $(0.136)$ & $(0.161)$ & $(0.118)$ & $(0.147)$ \\
\hline Child characteristics & Yes & Yes & Yes & Yes & Yes & Yes \\
\hline Household characteristics & Yes & Yes & Yes & Yes & Yes & Yes \\
\hline Time dummies & Yes & Yes & Yes & Yes & Yes & Yes \\
\hline \multirow[t]{4}{*}{ Constant } & 5.358 & -0.070 & -1.518 & $-2.076^{\star}$ & -0.084 & -1.594 \\
\hline & (5.695) & $(1.216)$ & $(4.962)$ & $(1.106)$ & $(2.688)$ & $(1.061)$ \\
\hline & \multicolumn{2}{|c|}{ Child stunting } & \multicolumn{2}{|c|}{ Child wasting } & \multicolumn{2}{|c|}{ Child underweight } \\
\hline & $\begin{array}{l}\text { More market } \\
\text { access }\end{array}$ & $\begin{array}{l}\text { Less market } \\
\text { access }\end{array}$ & $\begin{array}{l}\text { More market } \\
\text { access }\end{array}$ & $\begin{array}{l}\text { Less market } \\
\text { access }\end{array}$ & $\begin{array}{l}\text { More market } \\
\text { access }\end{array}$ & $\begin{array}{l}\text { Less market } \\
\text { access }\end{array}$ \\
\hline \multirow[t]{2}{*}{ Agricultural productivity } & $-0.082^{\star \star}$ & $-0.065^{\star}$ & -0.026 & 0.001 & -0.009 & -0.024 \\
\hline & $(0.039)$ & $(0.038)$ & $(0.019)$ & $(0.024)$ & $(0.024)$ & $(0.027)$ \\
\hline Child characteristics & Yes & Yes & Yes & Yes & Yes & Yes \\
\hline Household characteristics & Yes & Yes & Yes & Yes & Yes & Yes \\
\hline Time dummies & Yes & Yes & Yes & Yes & Yes & Yes \\
\hline \multirow[t]{2}{*}{ Constant } & -1.076 & $0.436^{*}$ & 0.817 & $0.402^{\star \star}$ & 0.155 & $0.509^{\star *}$ \\
\hline & $(1.296)$ & $(0.233)$ & $(0.787)$ & $(0.175)$ & $(0.601)$ & $(0.199)$ \\
\hline Observations & 3,475 & 3,447 & 3,475 & 3,447 & 3,475 & 3,447 \\
\hline
\end{tabular}

Source: Based on LSMS-ISA W1-2012 and W3-2016 survey in Nigeria.

Note: Enumeration area clustered standard errors in parentheses. ${ }^{*} p<0.10,{ }^{* *} p<0.05,{ }^{* *} p<0.01$.

We further allow for heterogeneity in the impact of agricultural productivity change by education of the household head. A dummy variable for a more educated household head is defined as the household head having attained an educational level above the median year of schooling in our sample, i.e., having 7 years of schooling or above.

The results (Table 5) indicate that agricultural productivity change has a positive significant impact on child HAZ for households having more educated heads. However, it has no significant impact on child HAZ for households with less educated household heads. Controlling for other factors, we find that a 10 percent increase in agricultural productivity change increase child HAZ by 0.04 and stunting 5 percent. Similar results were obtained by Abuya et al. (2012) in Kenya, Stamenkovic et al. (2016) in Serbia, and Fadare et al. (2019) in Nigeria - households with higher educational attainment will be more nutrition sensitive and have improved dietary habits and food choices, since poor dietary habits contributes to the poor nutritional status of underfives. Our findings imply that agricultural productivity growth alone may likely have only moderate impacts on malnutrition unless it is accompanied by improved educational outcomes. 
Table 5: Impact of agricultural productivity change on child nutritional outcomes by educational status of household head

\begin{tabular}{lcccccc} 
& \multicolumn{2}{c}{$\begin{array}{c}(1) \\
\text { Child HAZ }\end{array}$} & \multicolumn{2}{c}{$(3)$} & $(4)$ & \multicolumn{2}{c}{$\begin{array}{c}(5) \\
\text { Child WHZ }\end{array}$} & \multicolumn{2}{c}{$\begin{array}{c}\text { Child WAZ } \\
\text { More }\end{array}$} & $\begin{array}{c}\text { Less } \\
\text { educated }\end{array}$ & $\begin{array}{c}\text { More } \\
\text { educated }\end{array}$ & $\begin{array}{c}\text { Less } \\
\text { educated }\end{array}$ & $\begin{array}{c}\text { More } \\
\text { educated } \\
\text { educated }\end{array}$ & $\begin{array}{c}\text { Less } \\
\text { educated }\end{array}$ \\
& $0.382^{\star *}$ & 0.049 & -0.173 & 0.060 & 0.144 & 0.024 \\
Agricultural productivity & $(0.159)$ & $(0.103)$ & $(0.144)$ & $(0.103)$ & $(0.115)$ & $(0.070)$ \\
\hline Child characteristics & Yes & Yes & Yes & Yes & Yes & Yes \\
Household characteristics & Yes & Yes & Yes & Yes & Yes & Yes \\
Time dummies & Yes & Yes & Yes & Yes & Yes & Yes \\
Constant & -0.478 & 1.230 & -0.030 & -1.523 & -0.751 & -0.817 \\
& $(1.797)$ & $(1.953)$ & $(1.578)$ & $(1.498)$ & $(1.463)$ & $(1.181)$ \\
& Child stunting & Child wasting & Child underweight \\
& More & Less & More & Less & More & Less \\
& educated & educated & educated & educated & educated & educated \\
Agricultural productivity & $-0.067^{\star *}$ & -0.011 & -0.024 & -0.010 & -0.002 & -0.015 \\
& $(0.030)$ & $(0.017)$ & $(0.024)$ & $(0.012)$ & $(0.030)$ & $(0.016)$ \\
\hline Child characteristics & Yes & Yes & Yes & Yes & Yes & Yes \\
Household characteristics & Yes & Yes & Yes & Yes & Yes & Yes \\
Time dummies & Yes & Yes & Yes & Yes & Yes & Yes \\
Constant & $0.834^{\star *}$ & 0.052 & 0.081 & 0.303 & 0.113 & 0.054 \\
& $(0.347)$ & $(0.327)$ & $(0.260)$ & $(0.229)$ & $(0.350)$ & $(0.156)$ \\
\hline Observations & 3,096 & 3,826 & 3,096 & 3,826 & 3,090 & 3,823 \\
\hline
\end{tabular}

Source: Based on LSMS-ISA W1-2012 and W3-2016 survey in Nigeria.

Note: Enumeration area clustered standard errors in parentheses. ${ }^{*} p<0.10,{ }^{* *} p<0.05,{ }^{* \star} p<0.01$.

\section{Pathways from agricultural productivity change to child nutritional outcomes}

In this section, we identify the pathways on how agricultural productivity can affect child nutrition status. The results (Table 6) indicate that agricultural productivity change has a positive significant impact on total income and a positive, although not significant, impact on improving the food security of the household. This suggests that the income effects of agricultural productivity can positively influence nutrition outcomes indirectly through own-consumption routes. Headey (2011) and Webb and Block (2012) found that high agricultural growth rates were found to reduce stunting, possibly because of increased food expenditure. Our findings support those of Du et al. (2015), Sheahan and Barrett (2017), and Tomich et al. (2019) that agriculture policies and food prices which affect supply and demand can provide improved agricultural productivity, which leads to enhanced own consumption and which can foster dietary diversification and reduced undernutrition.

Table 6: Impact of agricultural productivity change on total income and household food insecurity status

\begin{tabular}{lc|c} 
& $\begin{array}{c}(1) \\
\text { Own } \\
\text { consumption }\end{array}$ & $\begin{array}{c}(2) \\
\text { Household months } \\
\text { food insecure }\end{array}$ \\
Agricultural productivity & $0.375^{\star \star *}$ & -0.017 \\
& $(0.117)$ & $(0.014)$ \\
\hline Child characteristics & Yes & Yes \\
Household characteristics & Yes & Yes \\
Time dummies & Yes & Yes \\
Constant & 2.686 & $0.547^{\star \star *}$ \\
& $(2.133)$ & $(0.178)$ \\
\hline Observations & 7,180 & 7,180 \\
\hline
\end{tabular}

Source: Based on LSMS-ISA W1-2012 and W3-2016 survey in Nigeria.

Note: Enumeration area clustered standard errors in parentheses. ${ }^{\star} p<0.10,{ }^{* \star} p<0.05,{ }^{\star \star \star} p<0.01$. 


\section{CONCLUSIONS AND POLICY IMPLICATIONS}

This study examines the effect of agricultural productivity change on child nutritional outcomes in Nigeria. Two-stage fixed effects models were specified and estimated - a first stage modeling changes in agricultural productivity and a second stage instrumental variable model linking agricultural productivity changes and child nutritional outcomes. Using several waves of micro-level panel data from Nigeria, we first show that high temperature (heat stress) reduces agricultural productivity change. A one percent increase in DHDD result in a 4 percent decrease in agricultural productivity.

Our analysis, more importantly, also provides important insights on the implications of agricultural productivity change on reducing child undernutrition. The results show that agricultural productivity growth has a positive effect on child nutritional outcomes. With a 10 percent increase in agricultural productivity change, child HAZ and WAZ increase by about 0.03 and 0.01 , respectively. The results reveal that an improvement in agricultural productivity reduces the prevalence of child stunting. An aggregate 10 percent increase in agricultural productivity change will reduce child stunting by 2 percent. We also examine heterogeneity in the impact of agricultural productivity changes on child nutritional outcomes through market access and education. The results show that agricultural productivity change has a higher impact for households that have better access to markets and in which the head of household has a higher level of education.

Based on our empirical findings, we suggest three key policy recommendations:

- Increase investment to enhance agricultural productivity: As our results show agricultural productivity strongly impacts child nutritional outcomes through 'own consumption' pathway and indirectly through incomes effects, investment in key agricultural sub-sectors, such as modern input supply, irrigation, mechanization, and extension services, could result in major improvements in food and nutrition security in Nigeria.

- Undertake complementary interventions in human capacity building: The findings show that increasing agricultural productivity is not enough to address fully child undernutrition challenges in Nigeria - the higher the education level of households the better the impact of agricultural productivity on child nutritional outcomes. Thus, incorporating complementary interventions in education and information dissemination about food choices, appropriate childcare, food preparation, sanitation, and food safety issues should be considered to maximize the benefits of agricultural productivity gains for nutritional outcomes.

- Improve market access to agricultural produce: Our results indicate that the impact of increased agricultural productivity on nutritional outcomes is higher for households with better market access. This is particularly important for households when agricultural productivity impacts on nutrition mainly through the 'income effects' pathway. Smallholders should therefore be linked with better markets to translate the full benefits of productivity gains into better child nutritional outcomes. 


\section{REFERENCES}

Abay, K. and K. Hirvonen. 2016. Does market access mitigate the impact of seasonality on child growth? Panel data evidence from northern Ethiopia. The Journal of Development Studies 53(9):1414-1429.

Abidoye, B.O. and A.F. Odusola. 2015. Climate change and economic growth in Africa: an econometric analysis. Journal of African Economies 24(2):277-301.

Abuya, B. A., Ciera, J., and E. Kimani-Murage. 2012. Effect of mother's education on child's nutritional status in the slums of Nairobi. BMC Pediatrics 12(1):80.

Adhiguru, P., and C. Ramasamy. 2003. Agriculture Based Interventions for Sustainable Nutritional Security. Policy Paper 17, National Centre for Agricultural Economics and Policy Research and Tamil Nadu Agricultural University, Coimbatore.

Alderman, H. and Headey, D.D. 2017. How important is parental education for child nutrition? World Development, 94:448-464.

Allendorf, K. 2007. Do women's land rights promote empowerment and child health in Nepal? World Development 35 (11):1975-1988.

Amare, M., Asfaw, S. and B. Shiferaw. 2012. Welfare impacts of maize-pigeonpea intensification in Tanzania. Agricultural Economics 43(1):27-43.

Amare, M., Jensen, N.D., Shiferaw, B. and J.D. Cissé. 2018a. Rainfall shocks and agricultural productivity: Implication for rural household consumption. Agricultural Systems 166:79-89.

Amare, M., T. Benson, O. Fadare, and M. Oyeyemi. 2018b. "Study of the determinants of chronic malnutrition in Northern Nigeria: quantitative evidence from the Nigeria demographic Health Survey. Food and Nutrition Bulletin 39(2): 296-314.

Anang, B.T., Bäckman, S. and T. Sipiläinen. 2020. "Adoption and income effects of agricultural extension in northern Ghana." Scientific African 7:219.

Aragón, F.M., Oteiza, F., and J.P. Rud. Forthcoming. "Climate Change and Agriculture: Subsistence Farmers' Response to Extreme Heat." American Economic Review: Economic Policy (forthcoming)

Asfaw, A., and A. Admassie. 2004. The role of education on the adoption of chemical fertilizer under different socioeconomic environments in Ethiopia. Agricultural Economics 30:215-228.

Barrett, C.B. 1996. On price risk and the inverse farm size-productivity relationship. Journal of Development Economics 51(2):193-215.

Behrman, J.R. and P. Taubman. 1986. Birth order, schooling, and earnings. Journal of Labor Economics 4(3): S121-S145.

Bellemare, M.F. 2013. The productivity impacts of formal and informal land rights: Evidence from Madagascar. Land Economics 89(2):272-290.

Belloumi, M. 2014. Investigating the linkage between climate variables and food security in ESA countries. Regional Environmental Change 42: 172-186.

Berti, P.R., Krasevec, J. and S. FitzGerald. 2004. A review of the effectiveness of agriculture interventions in improving nutrition outcomes. Public Health Nutrition 7(5):599-609.

Bhagowalia, P., Menon, P., Quisumbing, A.R. and J. Soundararajan. 2012. What dimensions of women's empowerment matter most for child nutrition. Evidence Using Nationally Representative Data from Bangladesh. Washington DC: International Food Policy Research Institute.

Black, R.E., Alderman, H., Bhutta, Z.A., Gillespie, S., Haddad, L., Horton, S., Lartey, A., Mannar, V., Ruel, M., Victora, C.G. and S.P. Walker. 2013. Maternal and child nutrition: building momentum for impact. The Lancet 382(9890):372-375.

Byerlee, D., De Janvry, A. and E. Sadoulet. 2009. Agriculture for development: Toward a new paradigm. Annual Review of Resource Economics 1(1):15-31.

Carletto, C., Zezza, A. and R. Banerjee. 2013. Towards better measurement of household food security: Harmonizing indicators and the role of household surveys. Global Food Security 2(1):30-40.

Chaijaroen, P. 2019. Long-lasting income shocks and adaptations: Evidence from coral bleaching in Indonesia. Journal of Development Economics 136:119-136.

Chijioke, O.B., Haile, M. and C. Waschkeit. 2011. Implication of climate change on crop yield and food accessibility in Sub-Saharan Africa. Centre for Development Research. Bonn: University of Bonn.

Christiaensen, L. 2011. Agriculture for Development in China 2030: Challenges and Prospects. Washington, DC: World Bank, mimeo.

Christiaensen, L., Demery, L., and J. Kuhl. 2011. "The (evolving) role of agriculture in poverty reduction—An empirical perspective." Journal of Development Economics 96(2):239-254. 
Christian, A. K., Wilson, M. L., Aryeetey, R. N., and A. D. Jones. 2019. "Livestock ownership, household food security and childhood anaemia in rural Ghana." PloS One 14(7).

Collier, P., \& S. Dercon. 2014. African agriculture in 50 years: smallholders in a rapidly changing world. World Development 63:92-101.

Cooper, M., Brown, M. E., Azzarri, C., and R. Meinzen-Dick. 2019. Hunger, nutrition, and precipitation: evidence from Ghana and Bangladesh. Population and Environment 41(2):151-208.

Danso-Abbeam, G., Ehiakpor, D. S., and R. Aidoo. 2018. Agricultural extension and its effects on farm productivity and income: insight from Northern Ghana. Agriculture \& Food Security 7(1): 1-10.

de Jager, I., Abizari, A.R., Douma, J.C., Giller, K.E. and I.D. Brouwer. 2017. Grain legume cultivation and children's dietary diversity in smallholder farming households in rural Ghana and Kenya. Food Security 9(5):1053-1071.

De Janvry, A. and E. Sadoulet. 2010. Agricultural growth and poverty reduction: Additional evidence. World Bank Research Observer 25(1):1-20.

Deryng, D., D. Conway, N. Ramankutty, J. Price, and R. Warren. 2014. "Global Crop Yield Response to Extreme Heat Stress under Multiple Climate Change Futures." Environmental Research Letters 9: 034011.

Donaldson, D. 2018. Railroads of the raj: Estimating the impact of transportation infrastructure. American Economic Review 108(4-5):899-934.

Donaldson, D. and R. Hornbeck. 2016. Railroads and American economic growth: A market access approach. The Quarterly Journal of Economics 131(2):799-858.

Donovan, K. 2016. Agricultural risk, intermediate inputs, and cross-country productivity differences. Unpublished Working Paper, South Bend, IN: University of Notre Dame.

Du, T., Kang, S., Zhang, J. and W.J. Davies. 2015. Deficit irrigation and sustainable water-resource strategies in agriculture for China's food security. Journal of Experimental Botany 66(8):2253-2269.

Duranton, G. 2015. Roads and trade in Colombia. Economics of Transportation, 4(1-2):16- 36.

Ecker, O. 2018. Agricultural transformation and food and nutrition security in Ghana: Does farm production diversity (still) matter for household dietary diversity? Food Policy. 79: 271-282.

Ehui, S. and J. Pender. 2005. Resource degradation, low agricultural productivity, and poverty in sub-Saharan Africa: pathways out of the spiral. Agricultural Economics 32:225-242.

Emerick, K. 2018. Agricultural productivity and the sectoral reallocation of labor in rural India. Journal of Development Economics 135:488-503.

Fadare, O., Amare, M., Mavrotas, G., Akerele, D., and A. Ogunniyi. 2019. "Mother's nutrition-related knowledge and child nutrition outcomes: Empirical evidence from Nigeria." PloS One 14(2).

FAO. 2016. Minimum Dietary Diversity for Women: A Guide for Measurement. Rome: Food and Agriculture Organization of the United Nations.

Fisher, M., Abate, T., Lunduka, R. W., Asnake, W., Alemayehu, Y., and R. B., Madulu. 2015. Drought tolerant maize for farmer adaptation to drought in sub-Saharan Africa: Determinants of adoption in eastern and southern Africa. Climatic Change 133(2):283-299.

Frison, E.A., Smith, I.F., Johns, T., Cherfas, J. and P.B. Eyzaguirre. 2006. Agricultural biodiversity, nutrition, and health: making a difference to hunger and nutrition in the developing world. Food and Nutrition Bulletin 27(2):167-179.

Funk, C., Peterson, P., Landsfeld, M., Pedreros, D., Verdin, J., Shukla, S., Husak, G., Rowland, J., Harrison, L., Hoell, A. and Michaelsen, J. 2015. The climate hazards infrared precipitation with stations-a new environmental record for monitoring extremes. Scientific Data 2: 150066.

Gaiha, R., Kaicker, N., Imai, K. and G. Thapa. 2012. Demand for Nutrients in India: An Analysis Based on the 50th, 61st and 66th Rounds of the NSS. Rome: IFAD.

Ghosh, A.K. 2007. The gender gap in literacy and education among the scheduled tribes in Jharkhand and West Bengal. Sociological Bulletin 56(1):109-125.

Gollin, D., Lagakos, D., and M. E. Waugh. 2014. Agricultural productivity differences across countries. American Economic Review 104(5):165-70.

Gómez, M. I., and K. D., Ricketts. 2013. Food value chain transformations in developing countries: Selected hypotheses on nutritional implications. Food Policy 42: 139-150.

Gowing, J. W., and M., Palmer. 2008. Sustainable agricultural development in sub-Saharan Africa: the case for a paradigm shift in land husbandry. Soil Use and Management 24(1);92-99.

Gulati, A., Kumar, A.G., Shreedhar, G. and T. Nandakumar. 2012. Agriculture and malnutrition in India. Food and Nutrition Bulletin 33(1):74-86. 
Haddad, L., and J., Meeker. 2013. A State-of-the-Art Review of Agriculture-Nutrition Linkages. AgriDiet Position Paper. <opendocs.ids.ac.uk/opendocs/

Hallman, K., Lewis, D. and S., Begum. 2003. An integrated economic and social analysis to assess the impact of vegetable and fishpond technologies on poverty in rural Bangladesh. Policy Brief. Washington, DC: International Food Policy Research Institute.

Hatab, A. A., Cavinato, M. E. R., \& C. J. Lagerkvist 2019. Urbanization, livestock systems and food security in developing countries: A systematic review of the literature. Food Security 11(2): 279-299.

Hausman, J.A. and W.E. Taylor. 1981. Panel data and unobservable individual effects. Econometrica: Journal of the Econometric Society 1377-1398.

Hawkes, C. and M.T. Ruel. 2008. From Agriculture to Nutrition: Pathways, Synergies and Outcomes. Agricultural and Rural Development Notes; No. 40. Washington, DC: World Bank.

Headey, D. 2011. "Rethinking the global food crisis: The role of trade shocks." Food Policy 36(2): 136-146.

Headey, D., Chiu, A. and Kadiyala, S. 2012. "Agriculture's role in the Indian enigma: help or hindrance to the crisis of undernutrition?" Food Security 4(1):87-102.

Headey, D., Hirvonen, K., Hoddinott, J., and D., Stifel. 2019. "Rural food markets and child nutrition." American Journal of Agricultural Economics 101(5):1311-1327.

Hendricks, N.P., and Peterson, J.M. 2014. Economic damages to agriculture from temperature increases: Decomposing the effects of heat exposure and water stress. Unpublished, Michigan State University.

Hirvonen, K., J. Hoddinott, B. Minten, and D. Stifel. 2017. "Children's diets, nutrition knowledge, and access to markets." World Development 95:303-15.

ILO (International Labour Organization). 2018. World Employment and Social Outlook 2018: Greening with jobs. Geneva: ILO.

IMF (International Monetary Fund). 2012, "Structural Transformation in Sub-Saharan Africa," Regional Economic Outlook. Washington, DC: IMF.

Irz, X., Lin, L., Thirtle, C. and S. Wiggins. 2001. Agricultural productivity growth and poverty alleviation. Development Policy Review 19 (4): 449-466.

Jagnani, M., Barrett, C.B., Liu, Y., You, L. 2019. Within-season producer response to warmer temperatures: Defensive investments by Kenyan farmers. Working Paper Series $N^{\circ} 314$. Abidjan, Côte d'Ivoire: African Development Bank.

Kadiyala, S., Harris, J., Headey, D., Yosef, S., and S. Gillespie. 2014. Agriculture and nutrition in India: mapping evidence to pathways. Annals of the New York Academy of Sciences, 1331:43-56.

Kassie, B. T., Van Ittersum, M. K., Hengsdijk, H., Asseng, S., Wolf, J., and R. P. Rötter. 2014. Climateinduced yield variability and yield gaps of maize (Zea mays L.) in the Central Rift Valley of Ethiopia. Field Crops Research 160:41-53.

Kassie, M., Teklewold, H., Marenya, P. Jaleta, M. and O. Erenstein. 2015, Production risk and food security under alternative technology choices in Malawi. Application of a multinomial endogenous switching regression. Journal of Agricultural Economics 66(3): 640-659.

Kim, J., Mason, N.M., Snapp, S., and F. Wu. 2019. Does sustainable intensification of maize production enhance child nutrition? Evidence from rural Tanzania. Agricultural Economics 50(6): 723-734.

Kumar, N., Harris, J., \& Rawat, R. 2015. If they grow it, will they eat and grow? Evidence from Zambia on agricultural diversity and child undernutrition. Journal of Development Studies 51(8):1060-1077.

Lagakos, D. and M. E. Waugh. 2013. Selection, agriculture, and cross-country productivity differences. American Economic Review 103(2):948-80.

Liu, O.L., Frankel, L. and K.C. Roohr. 2014. Assessing critical thinking in higher education: Current state and directions for next-generation assessment. ETS Research Report Series 2014(1):1-23.

Lobell, D. B., Bänziger, M., Magorokosho, C., and B. Vivek. 2011. Nonlinear heat effects on African maize as evidenced by historical yield trials. Nature Climate Change 1(1): 42-45.

Lobell, D.B., Hammer, G.L., McLean, G., Messina, C., Roberts, M.J., Schlenker, W. 2013. The critical role of extreme heat for maize production in the United States. Nature Climate Change 3: 497-501

Mariyono, J. 2019. Farmer training to simultaneously increase productivity of soybean and rice in Indonesia. International Journal of Productivity and Performance Management 68: 1120-1140

Masset, E. 2011. A review of hunger indices and methods to monitor country commitment to fighting hunger. Food Policy 36:S102-S108.

Matthew, O.A., Osabohien, R., Ogunlusi, T.O. and O. Edafe. 2019. Agriculture and social protection for poverty reduction in ECOWAS. Cogent Arts \& Humanities 6(1):1682107.

Mendola, M. 2007. "Agricultural technology adoption and poverty reduction: A propensity-score matching analysis for rural Bangladesh." Food Policy 32(3):372-393. 
Minten, B. and C.B. Barrett 2008. "Agricultural technology, productivity, and poverty in Madagascar." World Development 36(5):797-822.

Mutisya, M., Ngware, M. W., Kabiru, C. W., and N. B. Kandala. 2016. The effect of education on household food security in two informal urban settlements in Kenya: a longitudinal analysis. Food Security 8(4):743756.

Novella, N.S. and W.M. Thiaw. 2013. African rainfall climatology version 2 for famine early warning systems. Journal of Applied Meteorology and Climatology 52(3):588-606.

Parasuraman, S. and T. Rajaretnam. 2011. Agriculture, food security and nutrition in Vidarbha: a household level analysis. Economic and Political Weekly 42-50.

Potts, M.J. and S. Nagujja. 2007. A review of agriculture and health policies in Uganda with implications for the dissemination of biofortified crops. Washington, DC: HarvestPlus.

Powlson, D. S., Stirling, C. M., Thierfelder, C., White, R. P., and M. L. Jat. 2016. Does conservation agriculture deliver climate change mitigation through soil carbon sequestration in tropical agroecosystems? Agriculture, Ecosystems \& Environment 220: 164-174.

Ravallion, M. and G. Datt. 1999. When is growth pro-poor? Evidence from the diverse experiences of India's states. Washington, DC: World Bank.

Reimers, M., and S. Klasen. 2012. Revisiting the Role of Education for Agricultural Productivity. American Journal of Agricultural Economics 95 (1):131-152.

Rippke, U., Ramirez-Villegas, J., Jarvis, A., Vermeulen, S. J., Parker, L., F. Mer, et al. 2016. Timescales of transformational climate change adaptation in sub-Saharan African agriculture. Nature Climate Change 6(6): 605.

Ruel, M. T., Quisumbing, A. R., and M., Balagamwala. 2018. Nutrition-sensitive agriculture: What have we learned so far? Global Food Security 17:128-153.

Sauer, C.M., Mason, N.M., Maredia, M.K. and R. Mofya-Mukukua. 2016. The Role of Legume Technologies in the Agriculture-Nutrition-Food Security Nexus: Evidence from Zambia (No. 333-2016-14587).

Schlenker, W., Hanemann, W. M., \& A. C. Fisher. 2006. The impact of global warming on US agriculture: an econometric analysis of optimal growing conditions. Review of Economics and Statistics 88(1):113-125.

Schneider, K. and M.K. Gugerty. 2011. Agricultural productivity and poverty reduction: Linkages and pathways. Libraries Test Journal 1(1):56-74.

Sheahan, M., \& Barrett, C. B. 2017. Ten striking facts about agricultural input use in Sub-Saharan Africa. Food Policy 67: 12-25.

Shiferaw, B., Tesfaye, K., Kassie, M., Abate, T., Prasanna, B. M., and A., Menkir. 2014. Managing vulnerability to drought and enhancing livelihood resilience in sub-Saharan Africa: Technological, institutional and policy options. Weather and Climate Extremes 3: 67-79.

Stamenkovic, Z., Djikanovic, B., Laaser, U., and V. Bjegovic-Mikanovic. 2016. The role of mother's education in the nutritional status of children in Serbia. Public Health Nutrition, 19(15), 2734-2742.

Stifel, D., and B. Minten. 2017. Market access, well-being, and nutrition: evidence from Ethiopia. World Development 90: 229-241.

Tombe, T. 2015. The missing food problem: Trade, agriculture, and international productivity differences. American Economic Journal: Macroeconomics 7(3):226-58.

Tomich, T. P., Lidder, P., Coley, M., Gollin, D., Meinzen-Dick, R., Webb, P., \& Carberry, P. (2019). Food and agricultural innovation pathways for prosperity. Agricultural Systems, 172, 1-15.

Webb, P. and S. Block. 2012. Support for agriculture during economic transformation: Impacts on poverty and undernutrition. Proceedings of the National Academy of Sciences 109(31): 12309-12314.

Webb, P., \& E. Kennedy. 2014. Impacts of agriculture on nutrition: nature of the evidence and research gaps. Food and nutrition bulletin, 35(1), 126-132.

WHO Multicentre Growth Reference Study Group. 2006. WHO child growth standards. Length, height for-age, weight for-age, weight-for-length and body mass index-for age. Methods and development. Geneva: World Health Organization.

Wooldridge, J.M. 2010. Econometric Analysis of Cross Section and Panel Data. Cambridge, MA: MIT Press.

World Bank. 2017. Atlas of Sustainable Development Goals 2017: From World Development Indicators. World Bank Atlas. Washington, DC: World Bank.

Yosef, S., Jones, A.D., Chakraborty, B., and S. Gillespie 2015. "Agriculture and nutrition in Bangladesh: mapping evidence to pathways." Food and Nutrition Bulletin 36 (4):387-404.

Zeng, D., Alwang, J., Norton, G. W., Shiferaw, B., Jaleta, M., and C. Yirga. 2017. Ex post impacts of improved maize varieties on poverty in rural Ethiopia. Agricultural Economics 46 (4):515-526. 


\section{ABOUT THE AUTHORS}

Mulubrhan Amare is a Research Fellow in the Development Strategy and Governance Division (DSGD) of the International Food Policy Research Institute (IFPRI) working with IFPRI's Nigeria Strategy Support Program (NSSP), based in Washington, DC, USA. Bedru Balana is a Research Fellow with DSGD of IFPRI working with NSSP, based in Abuja, Nigeria. Adebayo Ogunniyi is a Research Analyst with DSGD of IFPRI working with NSSP, based in Abuja. 